\title{
The Christ in the cabaret: putting a blasphemous bar crawl on trial in Third Republic
}

\section{France}

Abstract: In May 1874, four workers in the French city of Roubaix were imprisoned after a night drinking resulted in scandalous acts towards a life-size statue of Christ on the cross. This article takes a micro-historical approach by recreating the events of this night through previously-unexplored archival material and newspaper reports from across the globe. The case became a potent example for individuals to attack either the danger of urban drinking spaces, workers' irreligion after the 1871 Paris Commune, or the abuses of the judicial system during the French 'Moral Order' clerical government of the early Third Republic.

Keywords: microhistory, drinking, religion, blasphemy, urban

Just before midnight on 21 April 1874, a police officer saw Jesus Christ shuffling up a street in the northern French city of Roubaix. On closer inspection, the officer realised this stumbling figure was actually a life-size, wooden statue of Christ on the cross, beer-soaked and damaged, carried on the back of the young Flemish blacksmith, Polydor Trachet. When the police officer asked where he was going with a strange "burden" at that hour, Trachet launched into a frantic account of the evening's events. A group of four workers had tricked him into carrying the statue on a night drinking in several cabarets, which had culminated in a "scandalous scene" in the final bar they visited, where revellers danced with the statue, dropped it repeatedly, and abused it in all manner of other ways. ${ }^{1}$ The workers were arrested the next day and appeared before a jury at the regional Assize Court the following month. In a theatrical trial, which tested the limitations of existing legislation and played to the jury's 
recent fearful memories of the Paris Commune, the four workers were found guilty of "outrage to the Catholic religion" and sentenced to jail terms between one month and a year.

This article is a microhistory of this ill-fated bar crawl and its aftermath. After reconstructing the events of the evening from the previously unexplored archival records of the police investigation, this article reveals three radically different retellings and ramifications the bar crawl had at the local, the national, and the transnational levels, revealing a unique moment in French politics, society, and culture.

Locally, the bar crawl became emblematic of the impact of rapid urban growth on the morality of the working population. No other city in France had a faster proportional population increase than the textile city of Roubaix, and the result was an drastic transformation of the urban environment, with dense, poor-quality housing crammed into alleyways behind exclusively working-class bars. This bar crawl vindicated the prejudices of Roubaix's middle-class onlookers - including the conservative local press, the police, and the city council - who could use the bar crawl to continue their spatialised moralisation of the urban environment.

The event took on national implications at the trial in May 1874. The early 1870 s were marked by conservative reaction in France following the trauma and sacrilege of the Paris Commune of $1871 .^{2}$ The period of 1873-9 was one that John McManners has described as a "halcyon period of Church-State co-operation", as President MacMahon's "Moral Order" government sought to restore stability to France through a closer alignment of the state and Catholic Church than had existed for decades. ${ }^{3}$ The zealous prosecutor at the trial stretched existing legislation to manipulate the jury to get his guilty verdict and to make an example of the men.

News of the trial's verdict spread via the press both in France as well as abroad. Thinking beyond just France, this was a period that historians Christopher Clark and 
Wolfram Kaiser have defined as a "culture war" in the West between Catholics and antiCatholics. ${ }^{4}$ Newspapers with editorial policies on either side of the conflict edited and reprinted scandalous stories like this to help their readers form horizontal bonds of solidarity across national borders, allowing Catholics to empathise with their peers in other countries, or permitting anticlericals to criticise the dangers of a deeply religious government.

After exploring these three reinterpretations of the events of 21 April, the article finishes by returning to the four imprisoned workers themselves and show how, through the appeals for clemency that they wrote through the rest of 1874, they were well aware of the symbolic importance that their ill-fated bar crawl had taken on beyond the city of Roubaix.

\section{May Jesus Christ enter the cabaret?}

Early in the evening of 21 April 1874, Louis Dessaux finished work at the textile factory and began his walk home. As he reached the centre of Roubaix, Dessaux stopped for a drink in the cabaret Cottégnie, where he saw his friend and fellow machinist César Lausent in the corner of the bar, enjoying a tankard of beer beside a wooden, life-size statue of Christ on the cross. ${ }^{5}$

As Dessaux ordered himself a beer, Lausent explained how he had attended a public auction on the nearby old "Galon d'Eau" road. When a lot at the auction containing the statue came up for sale, Lausent was heard to laugh: "So there it is! The Good Lord of Galon d'Eau!". Lausent paid twenty sous for the crucifix, claiming he could "make good use of it". When onlookers pushed him to elaborate, Lausent smirked and replied: "you will laugh tomorrow morning, when you hear that a calvary has been found in the countryside and people have cried 'miracle!'”. 6 
Lausent had not reckoned with the weight of a life-size wooden crucifix. He halfcarried, half-dragged it into the cabaret, where he struggled to work out how to execute his hoax. Draining his tankard, Lausent went out into the street, where he saw Polydor Trachet returning home after work. Lausent stopped the well-built blacksmith and offered him two francs to carry a "piece of wood" up to the nearby town of Tourcoing. Trachet accepted, though only realised what exactly he had agreed to when he followed Lausent back into the cabaret and discovered "a Christ instead of the piece of wood that had been advertised" to him. ${ }^{7}$ Still, the payment was tempting, so Trachet allowed the workers load the crucifix up onto his broad shoulders and the group set out northwards onto the Rue du Collège.

After leaving the cabaret Cottégnie, the group walked a thousand metres up the Rue du Collège, onto the Rue du Tourcoing. Here, at around seven p.m., they visited the cabaret Pecqueur; an hour, a round of beers, and a hundred and fifty metres later, the cabaret Devos; after another hour, another round, and a hundred and ninety metres, the cabaret d'Hellemmes. $^{8}$

At the cabaret Pecqueur, two Belgian-born workers who lived in the area joined the motley procession: Adolphe Baudour and Louis Wilfart. Baudour was a charismatic and easily-recognisable figure. He had a boisterous personality and a large red beard, and was the only one of the group who was known by name to the cabaret owners who were interviewed by the police the following morning. ${ }^{9}$

When the group reached the cabaret d'Hellemnes, César Lausent decided to play a trick on the barmaid. Entering alone, he asked her "may Jesus Christ enter" the cabaret? She had laughed, and said yes, assuming that "Jesus Christ" meant Baudour the bearded Belgian. She was understandably shocked when the whole group entered in fits of laughter, with Trachet reluctantly bearing the wooden Christ on his back. ${ }^{10}$ 
While the men drank in these cabarets, the statue would be propped against the wall, the bar, or the billiard table. During one journey from bar to bar, the statue fell, breaking an arm off when it hit the floor, which the men roughly reattached. ${ }^{11}$ Lausent began calling the statue what sounded like the French name "Henri". This came from the inscription INRI above the figure of Christ, standing for the Latin for "Jesus the Nazorean, King of the Jews". While it is difficult to gauge how blasphemous the intent behind this nickname was, it stuck, and the group were heard calling the statue "Inri" at various points in the night. ${ }^{12}$ The irreligious nature of this new name would be further compounded by the events in the cabaret Jouret on the Rue Turgot.

The group entered this fifth bar around ten o'clock. It was empty, apart from the cabaret owner Stéphanie Jouret working in the kitchen and her eighteen-year-old daughter Céline working at the bar. Once the workers bought their drinks, Baudour pushed the crucifix towards the unsuspecting Dessaux. Dessaux did not react, and the statue hit Lausent instead before slamming into the ground. The arm snapped off again, and the full contents of Lausent's tankard of beer spilled all over the statue. Although Trachet tried to rescue the statue, the workers snatched it from him and laughed as they pushed it between them, crying out "poor Inri!" whenever it fell. ${ }^{13}$

After half an hour, Wilfart decided to reattach the arm and asked for a hammer and nails. ${ }^{14}$ When he turned the wooden Christ upside down and began work, another round of laughter greeted him. Dessaux and Lausent grabbed the statue and took turns dancing with it, still upside down. Wilfart returned to the bar and asked the teenage barmaid for a cigar.

When she hesitated, the other three chanted "Yes, give us a cigar for Inri!" and she relented. ${ }^{15}$ More laughter rang out as Wilfart placed the cigar to the Christ's wooden lips.

The group stumbled outside around eleven. Baudour and Wilfart went to eat dinner at Baudour's next-door, while Lausent instructed Trachet to take the statue to another cabaret 
closer to Tourcoing and, once there, to order a bottle of hot wine. When Trachet reached this cabaret, he waited outside. When Lausent had not reappeared after an hour, Trachet carried the desecrated statue on towards Tourcoing. It was at this point that the police found him and he told his story. ${ }^{16}$

The following morning, the police took Trachet back to the cabaret Jouret, where the barmaid Céline denied that anything untoward had happened the previous night. As one of the two officers took out his notepad to begin a formal line of questioning, Céline's mother came out from the kitchen and made obvious gestures towards Trachet, as if to say "keep your mouth shut!". Trachet was not cowed, and declared "I will say what I saw!"17 The police arrested Lausent and the others later that day, and the cabaret Jouret was permanently closed down a day later. ${ }^{18}$

\section{The spatialisation of morality}

The police had barely begun their investigation when a version of the story appeared in the local press. Readers of the 24 April 1874 edition of the conservative Catholic daily, the Journal de Roubaix, found a provocative account of the bar crawl, which the author described as "one of the most scandalous affairs, which shows the degree of irreligion that some people have come to". ${ }^{19}$ In this retelling, "Mr X" and other "reprobates" spent the evening throwing beer onto the statue in various cabarets to amuse the gathered masses. At each cabaret they visited, "everyone" laughed at the "sacrilegious jests" of Mr X and his group, which only spurred them on.

With precise details yet to emerge, the editor - Alfred Reboux - seized on an opportunity to push an anti-cabaret agenda. First, by having the actions take place at multiple cabarets, rather than just at the cabaret Jouret, Reboux's article was less about the failings of 
a single drinking establishment: it was an article about the dangers of cabarets in Roubaix in general. Second, by referring to "Mr X" and by painting the nameless crowds in each of these cabarets as a captive audience, Reboux presented them as willing accomplices.

This attack would not be surprising to regular readers of the Journal de Roubaix. Alfred Reboux was continuing the crusade against cabarets that his father Joseph, founder of the newspaper in 1856, had pursued throughout the Second Empire. In January 1860, for example, he had written about a four-year-old child found drunk on the street with his parents "dead-drunk" in a nearby cabaret; in November 1862, he opened a report on a bar fight with "quarrels in cabarets are frequent"; the following October, he blasted landlords who continued to sell drinks to people in a state of extreme drunkenness. ${ }^{20}$ Reboux used these isolated stories to make broader statements about workers and their drinking spaces.

These attacks in the press reflected the language of contemporary police reports, which also tended to draw broad brushstrokes. In 1855, a police officer lamented that most workers had the "unfortunate habit" of spending all Sunday drinking in the cabaret while, by late 1859, another report described all Belgian workers as "abandon[ing] themselves to the most degrading passions and vices". ${ }^{21}$

The suspicion of working-class drinking spaces, as seen in the press and police, was not unique to Roubaix, and historians have explored similar attitudes in Paris to show that there was an institutionalised view in France that linked working-class drinking habits with their perceived social, moral, and biological degeneracy. ${ }^{22}$ What was unique to Roubaix, however, was the urban spatial relationship between working-class housing and drinking spaces that had intensified over the course of a generation. In 1857 there were 304 drinking establishments in Roubaix (one for every 128 people); by 1869 there were 700 (one for every 100 people), and by 1912 there would be 2,485 (one for every 49 people). ${ }^{23}$ 
These new cabarets were closely tied Roubaix's growth: no city in France witnessed a faster proportional rate of population growth in the nineteenth century, as migrant workers from the rural surroundings and from Belgium flocked to the ever-expanding textile factories. The bar crawl occurred at the end of one of the a period between 1851-76 when the population swelled from under 35,000 to just over $80,000 .{ }^{24}$ Unlike paternalist industrialists elsewhere in France, the textile industrialists of Roubaix rarely build houses for their new workers, leaving this to the private market. ${ }^{25}$ Speculative builders instead constructed thousands of houses in the alleyways off the main thoroughfares of the city, as the lack of planning regulations for buildings behind the main street frontage meant you could cram in as many houses as you could. ${ }^{26}$ These "courée" houses were often only one or two rooms, with appalling hygienic conditions, little access to air or light, and as many as thirty houses sharing a single open toilet at the end of the alley. The opportunistic nature of courée construction is reflected by the range of occupations of landlords: from painters to locksmiths, and from brewers to cabaret owners. ${ }^{27}$

Whether the landlord of the courée houses was a cabaretier or not, frequently one of the two buildings to either side of the entrance of a courée would be a cabaret. Inhabitants of the courée would invariably socialise in their cabaret. This was not necessarily to get drunk, but to eat, talk, and relax after work in the factory in a place that was less miserable and unhygienic than their homes. What this meant was that, while workers' alleyway houses were not immediately visible to passers-by, the cabaret at the entrance stood as a replacement image in the middle-class imaginary for worker domestic habits and behaviour.

Thus, at the time of this bar crawl, Roubaix was going through a disconcertingly rapid urban and demographic transformation, and middle-class onlookers often used the new cabarets as a stand-in in their minds for all worker behaviour beyond the factory. This wasn't helped by a national political environment which increasingly targeted worker drinking. ${ }^{28}$ In 
March 1873, the National Assembly declared public drunkenness a crime, and two months later, cabaret opening times were limited to 10 or $11 \mathrm{pm}$ in cities. ${ }^{29}$

The Roubaix city council was particular lax when it came to enforcing these laws. Instead, the council focused on rewarding workers who avoided the allure of the drinkinghall. From 1863, they started distributing prizes to the "best-kept" workers' houses. Henri Agache was a 39-year-old weaver who lived near a beerhall, but managed to keep his house "well kept, despite the great misery". ${ }^{30}$ Jean-Baptiste Lecomte, meanwhile, was the head of one of the 96 households the 1864 commission rewarded. The commissioners' brief description accompanying Lecomte's name described him as having "Raised the family very well no cabaret good conduct". ${ }^{31}$ The city council acknowledged that conditions of workingclass life were poor, but chose to single out these shining lights who did not to spend their evenings drinking.

Catholicism was another way that Roubaix's textile and municipal elite sought to counter the immorality they perceived in the working classes. Even in the Nord, described by Frédéric Barbier as the "citadel of militant Catholicism", Roubaix was marked by the strength of the devotion of its industrial elite. ${ }^{32}$ Thomas Kselman has shown how Roubaix had a particularly close alliance between clergy and industrialists, often to the chagrin of workers in the factories. ${ }^{33}$ Statues of the Virgin Mary were placed in visible positions in offices and shops, nuns acted as moral supervisors in women's workrooms, and industrialists set up Catholic worker circles from $1872 .{ }^{34}$

Yet, for all the fears of worker immorality and the "degree of irreligion that some people have come to", Roubaix's workers in fact demonstrated a much closer adherence to the Catholic faith than many workers elsewhere in France. Leslie Page Moch describes the workers of Roubaix in this period as "among the most religious in France" while Yves-Marie Hilaire identifies Roubaix as bucking the trend of working-class dechristianisation in the 
Nord: during the 1860s, at least two-thirds of people living in Roubaix attended regular masses and Easter services. ${ }^{35}$ This devotion was driven by the same group which the police signalled as the source of vice and degeneracy. The Belgian immigrants to Roubaix - who outnumbered French inhabitants by 1870 - had a much higher level of religious practice than longer-established worker communities like in nearby Lille. ${ }^{36}$

The enduring Catholic devotion of both Roubaix's elite and its migrant workers in the early 1870 s made the actions of Lausent and his group stand out all the more prominently. The spatialised morality, centred on the miserable courée, the corrupting cabaret, and the isolated "best kept homes", meant that Lausent and his group could be used to exemplify all that could be seen as wrong about Roubaisian cabarets and workers in 1874 .

This was reflected in the local police investigation into the character of the four men in the lead up to their trial. Dessaux had left his wife while she was pregnant and only returned to their house in a courée months after the child had died in infancy. ${ }^{37}$ The outcome of Baudour's report was equally damning. Not only was he notorious in Roubaix's cabarets, he was also rumoured to be having an affair with the teenage barmaid, Céline Jouret. He was publicly known to spend a lot of his time not in his courée home but, instead, next-door in the cabaret, where he had supposedly established "intimate relations" with Céline. ${ }^{38}$

The declaration at the start of the Journal de Roubaix article that this tale showed "the degree of irreligion that some people have come to" therefore served as a warning about "the people" as a whole in Roubaix as well as the places that "the people" frequented.

\section{Blasphemy, sacrilege, and "Outrage to the Catholic religion"}

In the first full year after the new March 1873 law on public drunkenness, there were 73,779 cases brought before the simple police courts in France. ${ }^{39}$ This drunken bar crawl was 
not one of these. Instead, the trial brought against them on 12 May 1874 was to be tried under the legislation on "outrage to the Catholic religion". 40

The usual victims of these laws were blaspheming journalists or newspaper editors: in 1860, the radical journalist Germain Casse was fined 200 Fr. for an article he had published while, a few months before this bar crawl in February 1874, the editor of La Démocratie du Midi was acquitted of "outrage to the Catholic religion" but found guilty of "outrage to public morality". 41

This was therefore to be a court case based on proving the men's blasphemy. As David Nash has argued, the history of blasphemy has been curiously understudied compared to other religious opposition like heresy, because blasphemy "could not be readily linked to coherent groups or indeed to coherent beliefs and doctrines". ${ }^{42}$ Broadly speaking, blasphemy is "the attacking, wounding, and damaging of religious belief", usually through verbal or printed means. ${ }^{43}$ These attacks, as Alain Cabantous has argued, were not always motivated by religious belief or lack thereof: blasphemy served a "social function" where people could refuse "the efforts of moral and religious education undertaken since the sixteenth century". ${ }^{44}$ However, as another historian of the term has argued, blasphemy perhaps "only exist[ed] in the mind of someone who felt offended, and not necessarily in that of the offender themselves" which means it is hard for us as historians to work out what blasphemy was intended and what, as Nash has said, were "nothing more than jokes that misfired" ${ }^{45}$

In terms of this bar crawl, there is another level that needs unpicking. While there were certain verbal acts of the evening which could be described as blasphemous - the cries of "poor Inri!", for example - many of the acts committed against the statue could be described more appropriately as acts of sacrilege: that is to say, the violation or physical damage of sacred objects. In many ways, this case echoed the events of France's most infamous sacrilege case from over a hundred years prior when, in 1765, Chevalier de la Barre 
supposedly disrespected a passing holy host, muttered blasphemous words, and damaged a crucifix in Abbeville. ${ }^{46}$ La Barre was executed in 1766, leading Voltaire to lambast the interfering role of the Church in Ancien Régime legal practice; a century later, however, and there was no law against sacrilege in France. ${ }^{47}$ As Mary Hartman has showed, even when the conservative government of Charles $\mathrm{X}$ forced through an anti-sacrilege law in 1825, almost half the Chamber of Peers rejected the utility of the term 'sacrilege' in post-Revolutionary France, wanting to replace it with 'public outrage'. ${ }^{48}$ This law was revoked in 1830 and was never enforced in its brief existence. Therefore, if the prosecution at Douai wanted to punish the workers for everything that took place on the bar crawl, they would have to find a way to let the physical insults committed to the statue be seen as a wider verbalised, premeditated attempt to insult and therefore punishable by the laws on blasphemy.

In the months before the bar crawl, Republicans in France had argued for the abolition of laws concerning press blasphemy, but the government quashed these oppositions. ${ }^{49}$ What's more, a change in policy from 1872 meant that these kinds of offences were now considered suitable to be tried by jury, which until then was usually only reserved for violent crimes involving bodily harm. ${ }^{50}$

The two above government policies are best understood in terms of the wider political context of the early 1870 s. France was in a period of reaction to the trauma of the Paris Commune of 1871, which had seen insurrectionaries declare the separation of Church and State, desecrate religious buildings, and execute priests and the Archbishop of Paris during the "semaine sanglante" of May $1871 .{ }^{51}$ In the immediate aftermath, members of the Catholic bourgeoisie established plans to build basilicas in Paris and Lyon to sit on hills and "thank God for victory over the socialists". ${ }^{52}$ The reaction intensified in May 1873 when the military commander who had led the bloody suppression of the Paris Commune, Marshall Patrice MacMahon, became president of the Third Republic. He declared that his government was 
one of "Moral Order": bringing religion back into closer alignment with the state to return society to "order and hierarchy". 53

Lausent's group had the misfortune of being prosecuted by someone who shared the Moral Order government's commitment to the place of religion in modern France. Arthur Desjardins was a young and ambitious lawyer, whose skill in jurisprudence was matched by his religious zeal. ${ }^{54}$ Desjardins had only been the public prosecutor at the Assize Court of Douai since 1873, and he would later be appointed advocate general to the highest court in France, the Paris Court of Cassation, in April 1875. ${ }^{55}$ Throughout his career, Desjardins ardently promoted the link between religious belief and national identity, culminating in his presidency of the multi-denominational League Against Atheism from 1893 until his death in $1901 .^{56}$

As the case was now suitable to be tried in front of a jury in the Assize Court, much of Desjardins's prosecution was focused on manipulating the pre-existing fears and prejudices of his jurors. All French juries in the Assize Courts were drawn only from the property-owning class. In Douai on 12 May 1874, the list of thirty-six prospective jurors (of whom twelve were chosen) was a catalogue of bourgeois professions, including two mayors and numerous merchants and manufacturers, three of whom were Roubaisian in origin. ${ }^{57}$ James Donovan has explored how this social homogeneity of juries, combined with the "ceremonial atmosphere" of Assize Courts meant that the result was "biased justice". ${ }^{58}$ This was further exposed by what Caroline Ford has described as "narrative" created by both prosecutors and defendants in nineteenth-century French cases. ${ }^{59}$ When he prosecuted this case, Desjardins used a masterful interrogation of the witnesses and an emphatic, theatrical closing speech to the jury to construct a narrative that elevated it from a drunken misdemeanour to a sustained, public parody of Catholic belief and an insult to France. 
Desjardins first established Lausent's premeditation. When questioned, Lausent told the court that he had bought the statue to sell it on for profit to the owner of the cabaret on the road to Tourcoing where Trachet was found. ${ }^{60}$ Desjardins ridiculed this "bizarre speculation", noting Lausent paid Trachet double the price he had bought the crucifix at the auction just to carry it. Lausent's defence crumbled against witness testimonies from the auction, where he was heard laughing about putting the statue to "good use" by installing it as a calvary between Roubaix and Tourcoing. Desjardins stressed that this early declaration meant that "the thought that dictated the purchase survived intoxication". ${ }^{61}$ In contrast to the Journal de Roubaix's coverage which emphasised the role of alcohol and cabarets, Desjardins suggested here that the insult had been carried out in spite of drunkenness, rather than because of it. Now, all the subsequent scandal and damage that occurred was maliciously irreligious, rather than just a drunken bar crawl gone wrong.

Desjardins picked up on Lausent's specific use of the term "calvary" at the auction which he presented as an obvious blow against regional Catholic devotional culture. Calvaries were shrines that depicted one of the fourteen Stations of the Cross - a scene from the story of the Crucifixion of Christ - to offer the devout a way to embark on a spiritual pilgrimage that echoed the events of the Passion. These shrines had been common at the junction of roads in Brittany, the north of France, and Belgium for centuries. ${ }^{62}$ Nicholas Saunders describes the importance of these "wayside shrines", stating that they "function[ed] both as navigational devices and objects of veneration... symbolically acquiring [the landscape] for the Christian faith". ${ }^{63}$

Desjardins argued that every act against the statue in the evening derived from Lausent's sober intention to "bring religion into ridicule". ${ }^{64}$ Desjardins treated the jury to his retelling of the bar crawl, where he paralleled the events with passages from the gospels. The Romans who had mockingly called Christ the King of the Jews were present in the men's 
jeering cries of "poor Inri!"; the falls and physical insults that Christ endured whilst carrying the cross were now the men pushing the wooden statue between one another; the wine with myrrh that was thrust towards Christ to drink was now the cigar which Wilfart forced to the statue's lips. Desjardins referred to a passage from the gospel of Matthew, which states: “And as they came out, they found a man of Cyrene, Simon by name: him they compelled to bear his cross". ${ }^{65}$ This moment, when the "foreign" Simon of Cyrene helped Jesus carry the cross, was one of the fourteen Stations of the Cross often replicated in calvary statues; in Desjardins's retelling, the man of Cyrene became the man of Belgium in the form of Trachet the foreign blacksmith who was tricked into carrying the statue.

The jury then heard Desjardins's closing argument as to why Lausent and his group could and should be legally punished, where he moved beyond regional devotional culture to stress the place of Catholicism in French national identity. The men had insulted the embodiment of "a national religion... which is associated with our intellectual development... a religion which is not only the mother of mankind, but is also the mother of France". Desjardins admitted that the 1820 s attempts to legislate against sacrilege had failed. Yet he pushed on and dramatically declared that, if these men had been able to insult the "emblem of the Christian religion" on 21 April, then what other sacred object, temple, or altar in France would be protected from such attacks? He closed his argument by offering the jury a glimpse at the future that awaited them if they did not make an example of the men: "if all of this can be insulted with impunity, then it shall be necessary to tear down the crucifix beneath which I speak to you", he finished, gesturing to the courtroom's crucifix which hung on the wall, "[and] to break it in front of you... None of these consequences escape you, and you know how you must apply the law", ${ }^{66}$

Nowhere in his speech did Desjardins make explicit reference to the Commune, but the message was clear. In his warning to the jury about the potential ramifications of failing 
to punish these workers and in his theatrical gesture to the courtroom's crucifix, Desjardins was making an implicit reference to the memory of these acts of violent sacrilege which were still so potently alive in the recent memory, as well as to the need to preserve the physical symbols of Catholicism in these fledgling years of MacMahon's government.

The jurors delivered a guilty verdict for all four men. ${ }^{67}$ Lausent was fined $300 \mathrm{Fr}$. and sentenced to a year's imprisonment, with six months for Dessaux and Baudour, and a month for Wilfart, reduced because he had cooperated with the police.

\section{The instrument and ally of political reaction}

MacMahon's Moral Order policies were just the latest battle in the long "war of the two Frances" between the forces of clericalism and anticlericalism. ${ }^{68}$ But this was also a time of clashes between these forces beyond just France. From Bismarck's Kulturkampf policies against the Roman Catholic Church in Germany from 1872 to the rising tensions in Belgium that would culminate in the 'school war' of $1879-84$, the 1870 s were marked by an increased “culture war" between clerical and anticlerical camps. ${ }^{69}$

This was also a transnational phenomenon, perhaps best seen through the ways that newspapers covered incidents like the 12 May trial. As Christopher Clark has argued, the Catholic press "created a discursive space that transcended national boundaries and nurtured the emergence of Europe-wide networks of communication and solidarity" for those who felt their religion was under attack while, at the other extreme, Wolfram Kaiser has shown how anti-Catholic newspapers "often printed or translated articles by foreign authors", meaning that "the energies generated by conflict in one state raised the emotional temperature among anticlericals in other states". ${ }^{70}$ Yvonne Maria Werner and Jonas Harvard have similarly argued that the increased "communicative landscape" of the press in the second half of the 
century helped the "powerful European cross-cultural phenomenon" of anti-Catholicism spread to readers across the Western world. ${ }^{71}$

On 14 May, the Gazette des tribunaux - a Parisian newspaper that focused on reporting court cases - carried a detailed transcript of the trial across its first two pages under the title of: "Outrage to the Catholic religion". ${ }^{72}$ This full coverage in a prominent place in the Gazette led to reprints of the court transcript in major Parisian papers, but conservative papers had already reported on the story before the trial had taken place. Louis Veuillot's ultramontane newspaper l'Univers reprinted the Journal de Roubaix's "degree of irreligion" article on 27 April. ${ }^{73}$ The conservative daily Le Figaro reprinted a version of the Gazette's transcript on 16 May. However, rather than bearing the title of the blasphemy law as the Gazette coverage had, this article was framed under the subheading: "Four sacrilegious workers". This change stressed both the fact the men were workers, and the sacrilege - rather than blasphemy - that they committed, calling back to the excesses of the Commune and brushing over the legal ambiguity of whether they could have been punished for sacrilege. The author also prefaced his coverage with the note that if the case had been tried in Paris instead of Douai, it "could not have failed to have a great[er] impact". ${ }^{74}$

This Parisian coverage helped transform the bar crawl and trial from a local issue to a national scandal. It was not long before conservative papers beyond France picked up the story of sacrilegious outrage, with stories printed in Catholic newspapers in Belgium and Holland between 17-21 May. ${ }^{75}$ These were either translations or edited versions of the original French coverage, spreading the scandal to their Catholic readers but not adding any new spin on the story. This was not the case when the story was printed in English-language newspapers.

Newspapers across Ireland used the story to highlight fears of anti-Catholicism both on the continent as well as closer to home. ${ }^{76}$ The 26 May edition of the Tralee Chronicle 
described the men as "shrieking all the time like fiends" on the bar crawl, "acting over again ... the insults offered to Our Lord before His Crucifixion.” The ambiguity of whether the men intended to parody the Passion had now disappeared, and Desjardins's interpretation was set in stone. The Irish context was emphasised in this article's closing: "We do not suppose that such a scene as the above is possible in England, heretical and infidel as it is". ${ }^{77}$

No longer isolated to Roubaix or even to France, the acts of Lausent and his group now stood as a symbol for all contemporary anti-Catholicism. On the other side of the world, the Sydney-based Catholic paper The Freeman's Journal reported the story on 1 August as "The spirit of Communism", ${ }^{78}$ Just as Irish coverage pointed to anti-Catholicism in England, this Australian newspaper also reframed the story in a way to have local significance. After describing the four workers' sentences, the piece finished: “These are the men whom Dr. Lang, a Christian minister, 'delighted to honour"'. This referred to the Presbyterian politician John Dunmore Lang, whose Republican and anti-Catholic views were widely known in Sydney at the time. ${ }^{79}$ By attaching the men's actions to a local anti-Catholic politician, the editor of this paper used the story to create a bond of solidarity between beleaguered Catholics in Australia and their coreligionists in Europe.

This pro-Catholic coverage in Ireland and Australia was adapted from an article that may have been intended for an audience with more anti-Catholic sensibilities. This 15 May article had been written by the French correspondent for the Times in London. ${ }^{80}$ While the prosecutor Desjardins had kept any reference to the Commune implicit in his closing speech on 12 May, the Times correspondent gleefully wrote "It is to be hoped ... that the efforts of the Communists to propagate their abominable doctrines have not been widely successful in France". After this provocative opening, the Times correspondent then described how the four men had carried the crucifix through the streets "as if it had been a Guy Fawkes". 
Since the re-establishment of the Catholic hierarchy in England in 1850, the use of the Guy Fawkes as a symbol for anti-Catholicism had witnessed a renaissance: Punch depicted Pope Pius IX as “The Guy Fawkes of 1850 preparing to blow up all England!” and effigies of the pope and his cardinals were burned across England on 5 November $1850 .{ }^{81}$ By the $1870 \mathrm{~s}$, the Guy Fawkes procession had a distinct working-class character, with Robert Storch arguing that "Guy Fawkes had been transmuted into a popular celebration with strong overtones of political and social protest". ${ }^{82}$ Unlike Catholic newspapers which reported the case with horror to establish transnational communities of solidarity, the use of the Guy Fawkes image here was an explicit nod to familiar, popular anti-Catholicism in England.

English coverage also extended to criticisms of Catholicism as a political force in MacMahon's Moral Order government. The Exeter and Plymouth Gazette ran an edited version of the Times piece on 16 May which mockingly described the workers as "sons of free-thought" and "martyrs of Roubaix" before expressing shock at how they were "heavily punished". The author finished with an overt attack on the overreach of the Church in France: "No wonder that the Republicans are dissatisfied with Marshal MacMahon's Government". ${ }^{83}$ Political criticisms of the extremes of Moral Order were even more explicit in a 16 May London Daily News article, where the author described the bar crawl and trial, then wrote that "[s]uch excesses as these occur only in countries where religion and irreligion are equally fanatical, and a dominant Church becomes the instrument and ally of political reaction". ${ }^{84}$ Now, rather than being illustrative of "the degree of irreligion that some people have come to", the event and trial together were now a parable for the dangers of an overlyreligious state like Moral Order France. 'Perhaps it were better for religion”, the piece closed, “if 'society,' as the Government for the time being is called in France, would leave such offenses to be dealt with in the ordinary way - by the police". 
With the overt criticism of MacMahon's government in these papers, it is surprising that there were few republican newspapers in France who sought to defend the men. One explanation for this is that the bar crawl of and subsequent trial came at the highpoint of MacMahon's press censorship of the major radical republican newspapers. ${ }^{85}$ Republican papers which were not directly impacted by the Moral Order's censorship regime nonetheless tempered the extremism of their views in this period. The Parisian paper L'Événementwhich Edmond Magnier founded in 1872 to be a 'Republican Figaro' -responded to MacMahon's press policies by retreating from their earlier overt republican and anticlerical views between from autumn 1873 , only returning to a more explicitly radical editorial stance in spring $1875 .{ }^{86}$ They discussed the trial in their 16 May edition, where the author described the men's acts as "the most odious outrage to religion one could think of". However, he also downplayed the premeditated and sinister nature of Lausent's acts by describing the men as “jeunes polissons": “delinquents" or "naughty young men". ${ }^{87}$

Joseph Magnin, the committed anticlerical politician and editor of the Dijon radical republican newspaper Le Progrès de la Côte-d'Or, told his readers on 15 May to go consult the Parisian Gazette if they wanted details of the trial, before writing 'I will abstain from making my reflections [on the case], which I'm sure you can figure out yourselves' ${ }^{88}$ Not far from Roubaix, Valenciennes's Echo de la Frontière questioned whether the case had deserved prosecution in such a prominent court as the Assize Court of Douai. ${ }^{89}$ This was a criticism of the 1872 change in legislation to permit non-violent offences like this to be tried by jury.

These two trends- downplaying the sinister and serious nature of the men's offences and questioning the whether they should have been tried on such a big stage - coalesced when Jewish journalist Michel Lévy wrote his 23 May article 'The sacrilege of Roubaix' for his journal L'Univers illustré. Dripping with sarcasm, Lévy opened his article "Four young 
men, four 'philosophes' of the city of Roubaix have just appeared before the Assize Court of the North, accused of outrages against the Catholic religion". He continued "Heaven forbid we raise in this mild chronicle a serious religious discussion about the mischief committed by imbeciles" who he believed to be "more stupid than wicked", 90

Lévy's focus was to question how Desjardins had achieved his guilty verdict without anti-sacrilege laws. "Was this gloomy madness a crime, [or] an offence of any kind falling under the law?" Rather than engaging in pro-Catholic or anti-Catholic interpretations, Lévy argued that the trial - and by consequence, others who had used the case to spark a 'serious religious discussion' - had transformed the events of 21 April 1874 into far more than they were.

\section{To serve as an example}

This idea that the case had been escalated by those on both, opposing sides of the $1870 \mathrm{~s}$ “culture war" was one that Louis Dessaux took up when he wrote to President MacMahon on 1 June 1874 to appeal his six-month sentence. Dessaux explained that he had been pressured into drinking which had led him to take part in the events that unfolded. ${ }^{91}$ However, he added "It can also be said that the local press has singularly enlarged the whole affair; some papers wanted to excuse our guilt, others exaggerated [it]". Dessaux received support in his appeal from an unlikely source: his employer, Alfred Motte-Grimonprez, who added a postscript to the letter in support. ${ }^{92}$ Although he belonged to the traditionally pious industrial elite, MotteGrimonprez signalled the beginning of a shift in the final quarter of the century: as the family's chronicler later described him, Alfred was one of "the first Republicans in the leading society of Roubaix". ${ }^{93}$ 
Dessaux was not alone in writing an appeal. On 20 June 1874, Adolphe Baudour's wife Lucie wrote to ask for clemency. Whereas Dessaux had blamed drink and the press, Lucie instead tried to stress the piety of her husband and family. Adolphe was, she wrote, a "good father and good husband, a good Catholic. He loves the Christian religion and sets a good example to our children". ${ }^{94}$ She wrote another appeal on 26 August, though neither was successful. A reason behind this might have been the police investigation into Adolphe Baudour's character ahead of the trial that revealed rumours of his adultery. As pious as Adolphe Baudour may have been at home in the courée, in the cabarets of Roubaix he succumbed to the kind of moral depravity which horrified middle-class onlookers.

César Lausent was serving a year-long imprisonment. ${ }^{95}$ His mother wrote several appeals through 1874 on his behalf. She was even more direct than Dessaux in blaming wider political forces for the harsh punishment of the four men when she wrote that "the penalty inflicted on my son was not for the gravity of the crime, but to serve as an example". ${ }^{96}$

The Justice Ministry in Paris seriously considered issuing a pardon to Lausent months after the trial. However, when they contacted Arthur Desjardins in December for his opinion, he remained steadfast that an appeal would lessen the symbolic punishment of the men and could lead to further attacks: inadvertently reinforcing the conclusion that Lausent's mother had reached.

Ironically, the example which Lausent and his fellows served was isolated to 1874 and to the zeal of a prosecutor whose personal faith reflected the government policy of Moral Order. Although MacMahon would remain president until 1879, when Léon Gambetta rose in the Chamber of Deputies on 4 May 1877 and declared 'Clericalism? That's the enemy!', he signalled a new shift in the battlegrounds of the culture war in France. ${ }^{97}$ After the fall of MacMahon's government, the Third Republic turned towards secularisation, most famously encapsulated by the Ferry Laws on education between $1879-86 .^{98}$ 
Rather than focusing on the lack of long-term legal or political repercussions of César Lausent's ill-fated prank, we should instead view this micro-history as a potent story which served as an easily accessible example for contemporaries across the globe to support different, pressing concerns about society, politics, and religion. From justifying fears about the impact of a rapidly growing urban environment on the moral character of the population, to sparking debates over the duty of government to support the Catholic faith in the traumatic aftermath of the Paris Commune, this "mischief committed by imbeciles" tapped into a transnational moment of Catholic and anticlerical debates in the early 1870 s.

\footnotetext{
${ }^{1}$ Archives départementales du Nord, Lille (hereafter ADN), 2 U 1/608, Gaston Meunier, 'Exposé des faits', 27 Apr. 1874.

${ }^{2}$ Peter Starr, Commemorating Trauma: The Paris Commune and its Cultural Aftermath (New York, 2006).

${ }^{3}$ John McManners, Church and State in France, 1870-1914 (New York, 1972), p. 39; Roger Price, The Church and State in France, 1789-1870 (Cham, 2017), p. 270.

${ }^{4}$ Christopher Clark and Wolfram Kaiser (eds.), Culture Wars: Secular-Catholic Conflict in Nineteenth-Century Europe (Cambridge, 2003).

${ }^{5}$ ADN 2 U 1/608, Adrien Gand (hereafter AG), 'Déposition du témoin - Louis Dessaux', 24 Apr. 1874.

${ }^{6}$ ADN 2 U 1/608, AG, 'Déposition du témoin - Alphonse Lézy', 27 Apr. 1874.

${ }^{7}$ ADN 2 U 1/608, AG, 'Déposition du témoin - César Lausent', 24 Apr. 1874; and idem. 'Commissaire de police de Roubaix, Interrogatoires', 22 Apr. 1874.

${ }^{8}$ ADN 2 U 1/608, Commissioner of police, map, s.d.; and 'Commissaire de police de Roubaix, Interrogatoires'.

${ }^{9}$ ADN 2 U 1/608, 'Ordre de conduite', 29 Apr. 1874

10 'Commissaire de police de Roubaix, Interrogatoires'.

${ }^{11}$ ADN 2 U 1/608, AG, 'Déposition du témoin - Polydor Trachet', 25 Apr. 1874.

${ }^{12}$ ADN 2 U 1/608, AG, 'Déposition du témoin - Louis Wilfart', 25 Apr. 1874.

${ }^{13}$ Ibid.

${ }^{14}$ Ibid.

${ }^{15}$ ADN 2 U 1/608, AG, 'Déposition du témoin - Stéphanie Jouret', 25 Apr. 1874; and idem., 'Déposition du témoin - Céline Jouret', 25 Apr. 1874.

16 'Déposition... Trachet'.

${ }^{17}$ ADN 2 U 1/608, 'Audition du témoin Morez', 25 Apr. 1874.

${ }^{18}$ ADN 2 U 1/608, Prefect of the Nord to Gaston Meunier, 23 Apr. 1874.

19 'Roubaix-Tourcoing', Journal de Roubaix (hereafter JR), 24 Apr. 1874.

${ }^{20} \mathrm{JR}, 14$ Jan. 1860, 7 Nov. 1862, and 30 Oct. 1863.

${ }^{21}$ Archives Municipales de Roubaix, Roubaix (hereafter AMR) 1 I 11, 'Rapport - Section Est', 20 Dec. 1855; idem. 'Rapport annuel', 1859.

${ }^{22}$ Ruth Harris, Murders and Madness: Medicine, Law, and Society in the Fin-de-Siècle (Oxford, 1991), pp. 243-84; and Susanna Barrows, 'After the Commune: alcoholism, temperance, and literature in the early Third Republic', in John M. Merriman (ed.),
} 
Consciousness and Class Experience in Nineteenth-Century Europe (New York NY, 1979), pp. 205-18.

${ }^{23}$ AMR 1 I 11, 'Rapport général sur les services de police', 1858; Désiré Bonnier,

'Amélioration de la condition morale \& physique de la population', Mémoires de la Société

d'émulation de Roubaix, 1, 1868-9 (1871), p. 104; and Gaston Motte, L'Urbanisation de

Roubaix au XIXe siècle (Roubaix, 1964), p. 26.

${ }^{24}$ John M. Merriman, 'Introduction', in John M. Merriman (ed.), French Cities in the

Nineteenth Century (London, 1982), pp. 12-14.

${ }^{25}$ Will Clement, 'The "Unrealizable Chimera": workers' housing in nineteenth-century

Mulhouse', French History, 32:1 (2018), pp. 66-85.

${ }^{26}$ Jacques Prouvost, 'Les courées à Roubaix', Revue du Nord, 51:201 (1969), p. 314.

${ }^{27}$ Ibid., p. 314.

${ }^{28}$ Susanna Barrows, "Parliaments of the people": the political culture of cafés in the early

Third Republic', in Susanna Barrows and Robin Room (eds.), Drinking: Behavior and Belief in Modern History (Berkeley, 1991), pp. 88-9.

${ }^{29}$ Ibid., p. 89; and W. Scott Haine, The World of the Paris Café: Sociability Among the

French Working Class, 1789-1914 (Baltimore, 1999), pp. 113-14.

${ }^{30}$ AMR 4 Q e 1, List of 65 households receiving prizes in 1863, 10 Oct. 1863.

${ }^{31}$ AMR 4 Q e 1, List of 96 households receiving prizes in 1864, 26 Jul. 1864.

${ }^{32}$ Frédéric Barbier, Le Patronat du Nord sous le Second Empire (Geneva, 1989), p. 28.

${ }^{33}$ Thomas Kselman, 'The varieties of religious experience in urban France' in Hugh McLeod (ed.), European Religion in the Age of Great Cities: 1830-1930 (Abingdon, 1995), pp. 168-9.

${ }^{34}$ David S. Landes, 'Religion and enterprise: the case of the French textile industry', in

Edward C. Carter, Robert Forster, and Joseph N. Moody (eds.), Enterprise and

Entrepreneurs in Nineteenth-and Twentieth-Century France (Baltimore, 1976), pp. 76-7.

${ }^{35}$ Leslie Page Moch, 'Infirmities of the body and vices of the soul: migrants, family, and urban life in turn-of-the-century France', in Leslie Page Moch and Gary D. Stark (eds.), Essays on the Family and Historical Change (Arlington TX, 1983), p. 48; and Yves-Marie Hilaire, 'Les ouvriers de la region du Nord devant l'Église catholique (XIXe et XXe siècles), Le movement social, 57 (1966), pp. 188-9.

${ }^{36}$ Jean Piat, Quand Mimerel gouvernait la France (Roubaix, 1992), p. 44; and Roger Price, Religious Renewal in France, 1789-1870: The Roman Catholic Church between Catastrophe and Triumph (Basingstoke, 2018), pp. 308-9.

${ }^{37}$ ADN 2 U 1/608, Police commissioner of Roubaix to Desjardins, 8 May 1874.

${ }^{38}$ ADN 2 U 1/608, Police commissioner of Roubaix to examining magistrate, 27 Apr. 1874.

${ }^{39}$ Yvernès, 'Documents statistiques relatifs à l'influence de l'alcoolisme sur la criminalité', Journal de la société statistique de Paris, 22 (1881), p. 76.

${ }^{40}$ ADN 2 U 1/608, 'Réquisitoire', s.d.

${ }^{41}$ Jean-Marie Mayeur and Arlette Schweitz, Les Parlementaires de la Seine sous la Troisième République, (Paris, 2001), pp. 130-1; and Journal des commissaires de police, 20 (1874), pp. 157-8.

${ }^{42}$ David Nash, 'Introduction: blasphemy', Journal of Religious History, 32:4 (2008), pp. 3934.

${ }^{43}$ David Nash, Blasphemy in the Christian World: A History (Oxford, 2007), p. 1.

${ }^{44}$ Alain Cabantous, Blasphemy: Impious Speech in the West from the Seventeenth to the Nineteenth Century, trans. Eric Rauth (New York, 2002), p. 197.

${ }^{45}$ Leonard W. Levy, Treason Against God: A History of the Offense of Blasphemy (New York, 1981), p. xi; and Nash, Blasphemy, p. 111. 
${ }^{46}$ Françoise Hildesheimer, 'La repression du blaspheme au XVIIIe siècle', in Jean Delumeau (ed.), Injures et blasphemes (Paris, 1989), p. 62; Richard Clay, 'Violating the sacred: theft and 'iconoclasm' in late eighteenth-century Paris', Oxford Art Journal, 26:2 (2003), p. 4. ${ }^{47}$ Voltaire, 'Le Cri du sang innocent (1775)' in Garnier (ed.), CEuvres complètes de Voltaire (1773 - 1776), (Paris, 1879), pp. 375-90.

${ }^{48}$ Mary S. Hartman, 'The Sacrilege Law of 1825 in France: a study in anticlericalism and mythmaking', The Journal of Modern History, 44:1 (1972), p. 31.

${ }^{49}$ Jacques de Saint-Victor, Blasphème. Brève histoire d'un “crime imaginaire” (Paris, 2016), p. 74 .

${ }^{50}$ Damon C. Woods, 'The French court of Assizes', Journal of Criminal Law and Criminology, 22:3 (1931), p. 325; and James M. Donovan, 'Not a right but a public function: the debate in the French National Assembly over the 1872 law on jury formation', French History, 21:4 (2007), pp. 395-410

${ }^{51}$ Starr, Commemorating Trauma.

${ }^{52}$ Karine Varley, Under the Shadow of Defeat: The War of 1870-71 in French Memory (Basingstoke, 2008), pp. 65, 216; and Bertrand Taithe, Citizenship and Wars: France in Turmoil, 1870-1871 (London, 2001), p. 102.

53 Jean-Marie Mayeur and Madeleine Rebérioux, The Third Republic from its Origins to the Great War, 1871-1914, trans. J. R. Foster (Cambridge, 1994), pp. 18-21; Kevin Passmore, 'Femininity and the Right: from moral order to moral order', Modern \& Contemporary France, 8:1 (2000), p. 56.

${ }^{54}$ Louis Renault, 'Notice sur la vie et les œuvres de M. Arthur Desjardins', Mémoires de l'Académie des Sciences Morales et Politiques de l'Institut de France, 25, (1907), p. 400. ${ }^{55}$ Ibid., p. 411; and Benjamin F. Martin, 'The courts, the magistrature, and promotions in Third Republic France, 1871-1914', The American Historical Review, 87:4 (1982), pp. 97884.

56 'Informations: La Ligue nationale contre l'athéisme', Journal des Débats Politiques et Littéraires, 10 Dec. 1893, p. 3.

${ }^{57}$ Woods, 'The French court of Assizes', p. 327; ADN 2 U 1/608, 'Liste des jurés', 12 May 1874.

${ }^{58}$ Donovan, 'Justice unblind', pp. $90-1$.

${ }^{59}$ Caroline Ford, 'Story-telling and the social imagery of religious conflict in nineteenthcentury French law courts', in Peter Coss (ed.), The Moral World of the Law (Cambridge, 2000), p. 162.

60 'Cour d'Assises du Nord, Audience du 12 mai', JR, 15 May 1874.

${ }^{61}$ Ibid.

${ }^{62}$ Eugène Royer and Joël Bigot, Les Calvaires Bretons (Paris, 1991).

${ }^{63}$ Nicholas J. Saunders, 'Crucifix, calvary, and cross: materiality and spirituality in Great War landscapes', World Archaeology, 35:1 (2003), p. 9.

64 'Cour d'Assises du Nord, Audience du 12 mai'.

${ }^{65}$ Matt. 27:32.

66 'Cour d'Assises du Nord, Audience du 12 mai', JR, 15 May 1874, p. 2.

${ }^{67}$ ADN 2 U 1/608, 'Cour d'assis du département du Nord. Déclaration du jury', 12 May 1874.

${ }^{68}$ Timothy Verhoeven, Sexual Crime, Religion and Masculinity in Fin-de-Siècle France : The Flamidien Affair (Basingstoke, 2018).

${ }^{69}$ Clark and Kaiser (eds.), Culture Wars.

${ }^{70}$ Christopher Clark, 'The New Catholicism and the European culture wars', in Clark and Kaiser (eds.), Culture Wars, pp. 23-4; Wolfram Kaiser, 'Clericalism - that is our enemy!': 
European anticlericalism and the culture wars', in Clark and Kaiser (eds.), Culture Wars, pp. 64-5.

${ }^{71}$ Yvonne Maria Werner and Jonas Harvard, 'European anti-Catholicism in comparative and transnational perspective. The role of a unifying other', in Yvonne Maria Werner and Jonas Harvard (eds.), European anti-Catholicism in comparative and transnational perspective (Amsterdam, 2013), pp. 17, 20.

72 'Outrage à la religion catholique', Gazette des Tribunaux, 14 May 1874.

73 'Nouvelles diverses', L'Univers, 27 Apr. 1874.

74 'Gazette des tribunaux... Quatre ouvriers sacrilgés', Le Figaro, 16 May 1874.

${ }^{75}$ Belgian coverage included Ghent's Le Bien Public, 17 May 1874 and Tournai's Courrier de l'Escaut, 21 May 1874, with a Dutch-language version printed in the Tilburgsche Courant, 21 May 1874.

76 'Public Blasphemy in France', Belfast News-Letter, 20 May 1874; and 'Blasphemous outrage in France', Downpatrick Recorder, 23 May 1874.

77 Tralee Chronicle, 26 May 1874.

78 'The spirit of Communism', The Freeman's Journal, 1 Aug. 1874.

${ }^{79}$ John Wolffe, 'Anti-Catholicism and the British Empire, 1815-1914', in Hilary M. Carey (ed.), Empires of Religion (Basingstoke, 2008), 47; and Benjamin T. Jones and Paul A. Pickering, 'A new terror to death: public memory and the disappearance of John Dunmore Lang', History Australia, 11:2 (2014), 127-34.

80 'France', The Times, 15 May 1874.

${ }^{81}$ Eleanor McNees, "Punch" and the pope: three decades of anti-Catholic caricature', Victorian Periodicals Review, 37:1 (2004), pp. 18-26; and Walter Ralls, 'The Papal Aggression of 1850: a study in Victorian anti-Catholicism', Church History, 43:2 (1974), pp. 242-56.

${ }^{82}$ Robert D. Storch, 'The policeman as domestic missionary: urban discipline and popular culture in Northern England, 1850-1880', The Journal of Social History, 9:4 (1976), pp. 1112.

${ }^{83}$ Exeter and Plymouth Gazette Daily Telegram, 16 May 1874.

${ }^{84}$ London Daily News, 16 May 1874.

${ }^{85}$ Pierre Albert, 'Histoire de la presse politique nationale au début de la Troisième

République (1871-1879)', (PhD thesis, 'IUniversité de Paris IV) (1980), v. 1, pp. 337-8.

${ }^{86}$ Ibid, v. 2, pp. 1307-14.

87 'Chronique des tribunaux', L'Événement, 16 May 1874.

88 'Correspondances spéciales', Le Progrès de la Côte d'Or, 15 mai 1874.

${ }^{89}$ L'Echo de la Frontière, 16 May 1874.

${ }^{90}$ Michel Lévy, 'Le sacrilége de Roubaix', L'Univers Illustré, 23 May 1874.

${ }^{91}$ Archives nationales, Paris (hereafter AN) BB/24/806, Louis Dessaux to President MacMahon, 1 Jun. 1874.

${ }^{92} \mathrm{AN}$ BB/24/806, Alfred Motte-Grimonprez to President MacMahon, 4 Jun. 1874.

${ }^{93}$ Gaston Motte, Les Motte: Etude de la descendance Motte-Clarisse 1750-1950 (Roubaix, 1952), pp. 90-1.

${ }^{94}$ AN BB/24/806, Lucie Dufranc to President MacMahon, 20 Jun. 1874.

95 ADN 2 U 1/608, 'Renseignements demandés sur César Lausent', 23 Apr. 1874; AN

BB/24/806, 'Ministre de Justice - Grâces et Réhabilitations, Rapport', 11 Dec. 1874.

${ }^{96}$ AN BB/24/806, Veuve Lausent to President MacMahon, 8 Aug. 1874.

${ }^{97}$ James McMillan, 'Priest hits girl': on the front lines in the 'war of two Frances', in Clark and Kaiser (eds.), Culture Wars, p. 77.

${ }^{98}$ Ibid., pp. 78-87. 